\begin{tabular}{c}
\hline Review of \\
ECONOMICS \\
and \\
INSTITUTIONS
\end{tabular}

Review of Economics and Institutions

ISSN 2038-1379 DOI 10.5202/rei.v3i2.76

Vol. 3 - No. 2, Spring 2012 - Article 2

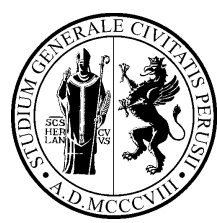

www.rei.unipg.it

\title{
Aid, Exports, and Growth: a Time-Series Perspective on the Dutch Disease Hypothesis
}

\author{
Joong Shik Kang \\ International Monetary
}

Fund

\author{
Alessandro Prati ${ }^{\dagger}$ \\ International Monetary \\ Fund
}

\author{
Alessandro Rebucci ${ }^{\bowtie}$ \\ Inter-American Development \\ Bank
}

\begin{abstract}
The available evidence on the effects of aid on growth is notoriously mixed. We use a novel empirical methodology, a heterogeneous panel vector-autoregression model identified through factor analysis, to study the dynamic response of exports, imports, and per capita GDP growth to a "global" aid shock (the common component of individual country aid-to-GDP ratios). We find that the estimated cumulative responses of exports and per capita GDP growth to a global aid shock are strongly positively correlated, and both responses are inversely related to exchange rate overvaluation measures. We interpret this evidence as consistent with the Dutch disease hypothesis. However, we also find that, in countries with less overvalued real exchange rates, exports and per capita GDP growth respond positively to a global aid shock. This evidence suggests that preventing exchange rate overvaluations may allow aid-receiving countries to avoid the Dutch disease.
\end{abstract}

JEL classification: F35; F43; 011

Keywords: aid, common factors, Dutch disease, growth, panel VARs, exchange rate overvaluation

\begin{abstract}
Manzoor Gill and Liudmyla Hvozdyk provided excellent research assistance. The authors thank anonymous referees, Andy Berg, Aart Kraay, Hashem Pesaran, Andrea Presbitero, Andy Powell, Lant Pritchett, Dani Rodrik, Rainer Schweickert, Antonio Spilimbergo, Arvind Subramanian, and Thierry Tressel, and conference and seminar participants at the 2007 Poverty Reduction, Equity and Growth Network meeting, the IMF and the IDB for useful comments on earlier drafts. All remaining errors are of the authors. The views expressed in this paper are exclusively those of the authors and not those of the IMF, the IDB, or their Executive Boards.
\end{abstract}

\section{$\dagger$ Acknowledgment to Alessandro Prati}

Alessandro Prati passed away on June 21, 2009 after a long and painful struggle with cancer. He lead us on this project with enthusiasm and energy, despite his illness, because he believed it was about a very important policy issue for low income countries. He last worked on it on March 4, 2009 that speaks eloquently to his commitment to research and policy work. We miss Alessandro sorely. We miss Alessandro the coauthor. We miss Alessandro the mentor. And we miss a very dear friend.

$\triangle$ Corresponding author. IDB Research Department, 1300 New York Avenue, NW, Washington DC, 20577, USA. (Phone +1 202623 3873, Fax +1 202623 2481. Email: AlessandroR@iadb.org).

\section{Recommended Citation}

Kang, J.S., Prati, A., \& Rebucci, A. (2012). Aid, Exports, and Growth: a Time-Series Perspective on the Dutch Disease Hypothesis? Review of Economics and Institutions, 3(2), Article 2. doi: 10.5202/rei.v3i1.76. Retrieved from http://www.rei.unipg.it/rei/article/view/76 


\section{Introduction}

The available evidence on the effects of aid on growth is notoriously mixed. Recently, Rajan and Subramanian (2008 and 2011) have suggested that "Dutch Disease" (DD) - that is, an aid-driven real exchange rate appreciation that reduces the size of the tradable sector and lowers exports, imports, and growth for some time - might be an important reason why foreign aid may not have a detectable positive effect on growth. In this paper, we revisit the issue of aid effectiveness and DD by taking a time series perspective, which better suits the empirical analysis of the dynamic implications of this hypothesis. Specifically, we study the dynamic response of aid-receiving countries' exports, imports, and per capita GDP growth (or growth for brevity) to a "global" aid shock (defined as the common component of each country's aid-to-GDP ratio). To do so, we use a heterogeneous panel vector autoregression model identified through factor analysis, which constitutes a novel methodological approach in this literature.

We find evidence consistent with a DD hypothesis, but also evidence that aid-receiving countries are not doomed to catch DD. Specifically, we show that a global aid shock can affect exports, imports, and growth either positively or negatively. As a result, the relation between aid and growth is mixed in the aggregate, consistent with the ambiguous results in the existing literature. But the sign with which aid affects exports and imports tends to be the same of that with which it affects growth in each country. In other words, for most countries in the sample, when aid reduces exports and imports, it also reduces growth; and, when aid increases exports and imports, it also increases growth. This positive comovement caused by a global aid shock - which is a novel empirical result that the previous literature, by focusing separately on either growth or exports, could not unveil (see below) - has two implications. First, the joint negative response of exports, imports, and growth to a global aid shock - which is typical of about half of the countries in the sample - is strongly suggestive of a DD mechanism at work. Second, given that the other half of the countries actually displays a healthy positive response of exports, imports, and growth to a global aid shock, it is clear that aid-receiving countries are not doomed to catch DD.

A question that these findings raise is what may determine the sign of these comovements in response to a global aid shock. In the paper, we show that the duration and intensity of exchange rate overvaluation periods in each aid-receiving country are negatively associated with the estimated responses of exports and growth to a global aid shock. Moreover, we also find that other standard growth covariates fail to account for the sign of this comovement. This is strong suggestive evidence of a causal link from aid to growth, via exchange rate overvaluation and export decline. At a minimum, this evidence does not contradict the interpretation of the comovements that we document on the DD hypothesis, and points to exchange rate policy as 
an important policy area of focus to identify policy actions that permit countries to avoid DD. The paper therefore not only provides direct evidence of the joint effects of aid on exports, imports, and growth that is novel in the literature, but also explains, or at least interprets, such evidence in terms of a close association between these comovements and measures of exchange rate overvaluation 1 .

The empirical methodology used in this paper has several distinctive features. First, we investigate a "weak" form of the DD hypothesis, namely whether export performance deteriorates in response to a temporary aid shock, curtailing import possibilities and temporarily reducing growth. In standard DD models, growth is endogenous with learning-by-doing in the export sector generating positive externalities that enhance productivity growth in the entire economy. In these models, any appreciation of the real exchange rate resulting from an aid shock-even if it is temporary-leads to a reallocation of resources away from the tradable sectors and a permanent loss of productivity growth (see, for instance, Sachs and Warner, 1995). However, the well-known fact that growth is not persistent (see, for instance, Easterly, Kremer, Pritchett, \& Summers, 1993 and Rodrik, 1999) rules out this "strong" form of DD ${ }^{2}$ As we can see in Table 1, per capita growth is not persistent in our sample of aid-receiving countries. ${ }^{3}$ Aid, export and import ratios, albeit more persistent than growth, must also be stationary according to Table 1. Thus, aid shocks cannot affect trend growth in our data, as it is implied by standard DD models. Nonetheless, aid inflows can cause temporary growth losses, which permanently reduce income per capita (a key measure of standard of living) with potentially large welfare implications. This is the "weak" form of DD hypothesis that we shall investigate in the paper.

Second, the empirical methodology we use in this paper also differs from the one typically used in the literature on aid and growth for the novel approach adopted to identify exogenous aid changes. The approach we follow relies on using the common component of individual recipients' aid-toGDP ratios (i.e., the common factor of country-specific aid-to GDP ratios) rather than trying to find an instrumental variable as an exogenous source of aid variation. This common aid component, which we call "global aid," captures donors' common aid policies, such as the promised surge in aid

\footnotetext{
${ }^{1}$ Examining the precise mechanisms and policy conditions that allow some countries to limit the real exchange rate appreciation possibly associated with aid inflows, and thus possibly avoiding DD is beyond the scope of this paper. See Cerra, Tekin, and Turnovsky (2008) for a theoretical analysis of the role of exchange rate policy in determining the effects of foreign aid on output. See Berg et al. (2007) for an extensive, but not model based, discussion of such policy conditions.

2 This basic fact also represents an empirical challenge for endogenous growth theory. See Jones (1995) for a provocative discussion of the U.S. case.

${ }^{3}$ This is confirmed by formal unit tests not reported but available from the authors on requests.
} 
flows toward meeting the millennium development goals, the Heavily Indebted Poor Countries (HIPC) initiative, or the Cold War, and, by construction, does not respond to economic developments in individual recipient countries. At the same time, it correlates well with aid series of individual countries, as evidenced by the fact that the first principal component of the aid-to-GDP series in our sample explains about 45 percent of their variance. Therefore, global aid is a novel solution to the simultaneity bias stemming from the two way causation between aid and growth. ${ }^{4}$

In addition, to make sure that with global aid we identify the effect of exogenous shifts in donors' policies, and not that of other common factors that might be associated with global aid, we add to the model control variables for the global business cycle and global waves of trade liberalization. To control for the global business cycle we use an index of commodity export prices and a measure of import demand by trading partners from the IMF World Economic Outlook database. To control for the global waves of trade liberalization we include the index of trade openness of Wacziarg and Welch (2008).

An identification strategy based on global aid has similarities and differences with the traditional instrumental variable approach. Our attempt at isolating a measure of aid flows that reflects only donors' policies that are independent from country-specific economic circumstances is akin to that of Rajan and Subramanian (2011), who propose an instrument based on the non-economic determinants of donors' aid policies. In the same spirit, other studies have earlier included the arm imports of aid-receiving countries in the set of instruments (see, e.g., Burnside and Dollar 2000, Hansen and Tarp 2001, and Clemens, Radelet, and Bhavnani 2004). However, some of these instruments, such as arm imports, capture exogenous sources of variation in aid that correspond to forms of tied aid - i.e., bilateral aid to be spent on imports from the donor country - whose conditions may constrain and distort the growth effects of aid. Global aid is, instead, a source of exogenous variation in each country's aid series that is less likely to constrain the economy's response to it. In addition, while instruments based on the non-economic determinants of donor policies are suitable for cross-sectional analysis, our global aid measure can be used to track the effects of aid over time, and its comovements with exports, imports, and per capita GDP growth, which are critical to investigate the DD hypothesis.

Another novel feature of our methodology is that the panel vector-autore-

$\overline{4}$ Country-specific aid flows could be endogenous because well-intentioned donors may give more aid to countries that are growing more slowly. This form of endogeneity will generate a spurious negative correlation between aid and growth and bias downwards any estimated positive causal effect of aid on growth. It is also possible that donors might be more willing to give aid to those poor countries that are growing faster because they expect successful countries to make better use of their aid. In this case, a spurious positive correlation between aid and growth would tend to bias upwards any estimated positive effect of aid on growth. 
gression approach allows us to study the joint response of growth and exports, and imports to a global aid shock. By tracing the joint effects on these variables, we can verify whether any effect of aid on growth is associated with a matching effect on exports and imports consistent with the weak form of the DD hypothesis we are focusing on. In contrast, the existing literature on aid and DD has concentrated only on either the growth or the export channel, without checking for the matching effect in the other variable or on imports. For instance, Prati and Tressel (2006) focused only on the effects of aid on exports without considering the broader consequences for growth, while Rajan and Subramanian (2008) investigated whether output in export-oriented, labor-intensive manufacturing industries grow more slowly than other industries in countries that received more aid. But they did not check whether slower output growth in these sectors do affect negatively overall export as theory would predict.

Joint modelling of export, import, and growth does not only permit to check the presence of matching effects on export and growth that the existing literature has not yet investigated, but also to shed some light on the possible mechanism through which these effects may come about. In particular, realistically assuming that the aid-receiving countries do not have access to private international capital markets, we can expect that an aid inflow that mostly finances imports in excess of what can be purchased by export revenue, should put relatively less upward pressure on non-tradable prices and the real exchange rate, with a less negative (or more positive) impact on exports. Vice versa, an aid inflow that is spent mostly on domestically produced goods will result in a stronger appreciation of the exchange rate and lower exports.

Finally, our panel vector-autoregression model allows for the maximum degree of parameter heterogeneity by estimating a separate VAR model for each country. Other papers allow for some, albeit much more limited, heterogeneity in the impact of aid inflows on growth and exports. For instance, Burnside and Dollar (2000) rely on a composite policy measure that combines trade policy, inflation, and budget balance to allow the effect of aid on growth to vary according to the quality of such policies across countries. Dalgaard, Hansen, and Tarp (2004) and Roodman (2007) argue that aid's effectiveness depends on the geographical location of the recipient and show how aid has positive effects on growth outside the tropics. Clements et al. (2004) distinguish between short- and long-term impact of aid and present evidence supporting the effectiveness of the former. All these studies select a possible source of heterogeneity ex-ante and then interact it with the aid variable in the regressions. In contrast, we first document the heterogeneous response of growth, exports, and imports to a global aid shock across countries. Then we investigate this heterogeneity in a second stage of the analysis by regressing the estimated response to aid shocks for each country on a large set of variables typically considered in the growth literature 
- including institutional quality, geography, aid composition, and measures of the macroeconomic policy stance as well as measures of exchange rate overvaluation. Therefore, in this second stage of the analysis, unlike Rajan and Subramanian (2008 and 2011), we implicitly allow for other hypotheses that might explain the heterogenous response of exports and growth to an aid shock. In sum, as far as we know, this paper is the first in the literature to investigate the DD hypothesis by looking at the joint impact of aid on growth, exports, and imports, and also allowing for alternative explanatory hypothesis to be considered in the analysis.

The rest of the paper is organized as follows. Section 2 discusses the methodology we use. Section 3 presents our data set. Section 4 reports the estimation results and discuss their interpretation. Section 5 concludes.

\section{Methodology}

The empirical model we use in the analysis is a stationary, heterogenous panel vector-autoregression (PVAR) - e.g., Holtz-Eakin, Newey and Rosen (1988) and Attanasio, Picci, and Scorcu (2000), Canova and Ciccarelli (2004). In this model, we then identify a global aid shock by means of factor analysis (e.g, Forni \& Reichlin, 1998) of the aid-to-GDP series of all countries in our sample. Thus, in this section, we present the empirical model and discuss its estimation and identification.

\subsection{Empirical Model}

We model the cross section of endogenous variables we focus on, collected in the vector $Z_{t}^{i}$, as the following stationary, heterogenous PVAR:

$$
\begin{aligned}
B_{0}^{i} Z_{t}^{i} & =B^{i} Z_{t-1}^{i}+C^{i} X_{t}^{i}+\mu^{i}+\xi^{i} t+\varepsilon_{t}^{i} \\
i & =1, \cdots N ; t=1, \cdots T
\end{aligned}
$$

where $X_{t}^{i}$ is a vector of country-specific control variables, $\varepsilon_{t}^{i}$ is a 4-dimensional vector of serially and cross-sectionally uncorrelated innovations with variance-covariance matrix $\Omega^{i}, \mu^{i}$ is a 4-dimensional vector of country specific effects, and $t$ is a time trend, and $B_{0}^{i}, B^{i}, C^{i}, \xi^{i}$ are matrices of coefficients. $N$ is the number of countries in the sample and $T$ is the number of time periods (i.e., years).

We include four variables in $Z_{t}^{i}$. In addition to our measure of global aid (discussed in more detail below), we include per capita GDP growth, the export-to-GDP ratio, and the import-to-GDP ratio.5 The inclusion of GDP

\footnotetext{
5 Per capita GDP growth is from the Penn World Table. The data for the export-to-GDP ratio and the import-to-GDP ratio are from the IMF International Financial Statistics. To measure aid at the at individual country level, we use the standard OECD concept of "net official development assistance." We enter aid, import and export as share of GDP as opposed to real per capita terms because, as GDP shares, these variables are linked by
} 
growth and export does not need justification. ${ }^{6}$ We include imports in the country VAR specification to help interpret more clearly the comovement that we shall document in the next section between export and growth in response to a global aid shock. Specifically, the rationale is that, depending on how large the response of imports to an aid shock is, the impact of the aid shock on the real exchange rate and on exports may vary. In the limit, for instance, if all aid is spent on imports, there should be relatively less upward pressure on non-tradable prices and the real exchange rate, and a less negative (or more positive) response of exports. Vice versa, if all aid is spent on domestically produced goods, the impact on domestic prices and the exchange rate should be larger, with a worse export performance. Observing the import response and comparing it to that of export is informative on the channel of transmission that may be at work.

Note that we do not include the real exchange rate in the country VAR models as in principle we could do. We do so to able to conduct a "horse race" with other variable typically considered in the empirical growth literature in the second stage of the analysis - the part of the analysis in which we try to explain the varying impact of aid on growth and export. Including a time series for the real exchange rate in the VAR model would prevent us from comparing, in the second stage of the analysis, the explanatory power of measures of real exchange rate overvaluation with that of other potential determinants of the heterogeneity in the response of growth, exports, and imports to global aid shocks. Many variables typically used in the empirical growth literature, in fact, have no time series dimension - e.g., broad measures of institutions - and can then only be considered in the context of a pure cross-section analysis.

All variables included in $Z_{t}^{i}$ are assumed to be covariance-stationary.7 A temporary aid shock is thus expected to affect per capita growth and the trade shares only temporarily, with possible permanent effects on the cumulative response of these variables, and hence on cumulative trade flows and per capita GDP growth. Given that we use annual data, we include only one lag of $Z_{t}^{i}$ because adding more lags to the VAR specification would use up degrees of freedom and would not be feasible statistically. The VAR specification is also the same for all countries to avoid introducing differences in country responses due to different model specifications, and because it would be practically difficult to search for a data-congruent specification

balance of payments identity under the assumption that aid-receiving countries have no access to private international capital markets.

${ }^{6}$ We enter aid, import and export as share of GDP as opposed to real per capita terms because, as GDP shares, these variables are linked by balance of payments identity under the assumption that aid-receiving countries have no access to private international capital markets.

7 See Table 1 for descriptive statistics on this assumption. Preliminary evidence supporting this hypothesis based on standard unit root tests is not reported but is available from the authors on request. 
for each considered country. The vector of controls $X_{t}^{i}$ includes two sets

Table 1 - Growth, Aid, and Trade Flow Persistence: Sample Autocorrelations

\begin{tabular}{ccccc}
\hline \hline & Per capita GDP growth & Aid-to-GDP & Export-to-GDP & Import-to-GDP \\
\hline Mean & 0.10 & 0.69 & 0.74 & 0.70 \\
Median & 0.15 & 0.75 & 0.80 & 0.79 \\
Stdev. & 0.19 & 0.22 & 0.24 & 0.28 \\
\hline \hline
\end{tabular}

of variables. The first is a set of dummies for wars and natural disasters, and associated emergency aid flows, to avoid that large outliers in the time series data distort the VAR estimates at the country level. 80 The second set includes three variables: (i) a real commodity export price index, (ii) an index of trading partners's import volume growth, as well as (iii) an index of trade liberalization. 9 These variables play a specific role in our identification strategy, and hence their inclusion is discussed in more detail below together with the identification of the global aid shock.

\subsection{Estimation}

To estimate the model above, we use the mean group estimator of Pesaran and Smith (1995) and Pesaran, Smith, and Im (1995). This is a standard technique for the estimation of dynamic panel data models with heterogenous slope coefficients. $\sqrt{10}^{10}$ The technique involves estimating the VAR model above country-by-country, with ordinary least squares, and then taking averages of the estimates (e.g., impulse responses or variance decompositions) across countries. We use arithmetic averages, but we also computed weighted averages, weighting by the inverse of the standard error of the individual impulse response and the variance decompositions, and found similar results (not reported). Note here that, as Lee et al. (1998) illustrated, a standard dynamic growth regression that allows for the possibility of slope-heterogeneity (i.e., a standard dynamic panel data model with heterogeneous slope coefficients) would have to be estimated with the same technique. This is because fixed effect, random effect, and instrumental variable estimators are inconsistent in a dynamic panel data model under

8 Specifically, we include the following dummy variables: (1) Dummy for the years of war; (2) Dummy for the years of civil war; (3) Dummy for the three years of postconflict after the end of war or a civil war; (4) Dummy for the years of earthquake; (5) Dummy for the years of drought; (6) Dummy for the years of flood or windstorm.

9 The source of the data are the IMF World Economic Outlook database and Warcziag and Welch (2008), respectively.

${ }^{10}$ See Lee, Pesaran, and Smith (1998) for an application of this techniques to the empirical growth literature. The literature that extends this estimation approach to PVAR models is surveyed by Smith and Fuertes (2007). Rebucci (2010a) provides Monte Carlo evidence on the performance of this estimator relative to a fixed effect estimator and instrumental variable estimator. See Rebucci (2010b) for an application. 
slope heterogneity (Pesaran \& Smith, 1995).

A second important point to note is that, in the estimation of the country VARs, for simplicity, we do not impose the exclusion restrictions that lagged growth, export, and import do not affect global aid in each country i, i.e., the matrix $B^{i}$ in equation (1) is unrestricted. As we shall see below these restrictions are not necessary for identification purposes (absence of contemporaneous impact of country variables on global aid is sufficient for identification purposes), while they would complicate the estimation procedure considerably and unnecessarily. In fact, imposing such restrictions could yield only efficiency gains, but all the results of the paper can be derived without using the standard errors of the country estimates. So the main results reported in the paper would not be affected by imposing such restrictions. We also regard the technical simplicity of the analysis that we implement as an important advantage of the approach we propose.

\subsection{Identification of a global aid shock}

Identification of the global aid shock naturally follows from focusing on the common component of individual country aid-to-GDP ratios. The common component of individual aid-to-GDP series, can be interpreted as representing donors' common aid policies, such as aid policies associated with the Cold War, the Heavily Indebted Poor Countries (HIPC) initiative, or more recently the Millennium development goals and the associated promised surge in aid. The common component of individual aid-to-GDP

Figure 1 - Global Aid ( i.e., Average Aid-to-GDP, 1966-2002) 1/

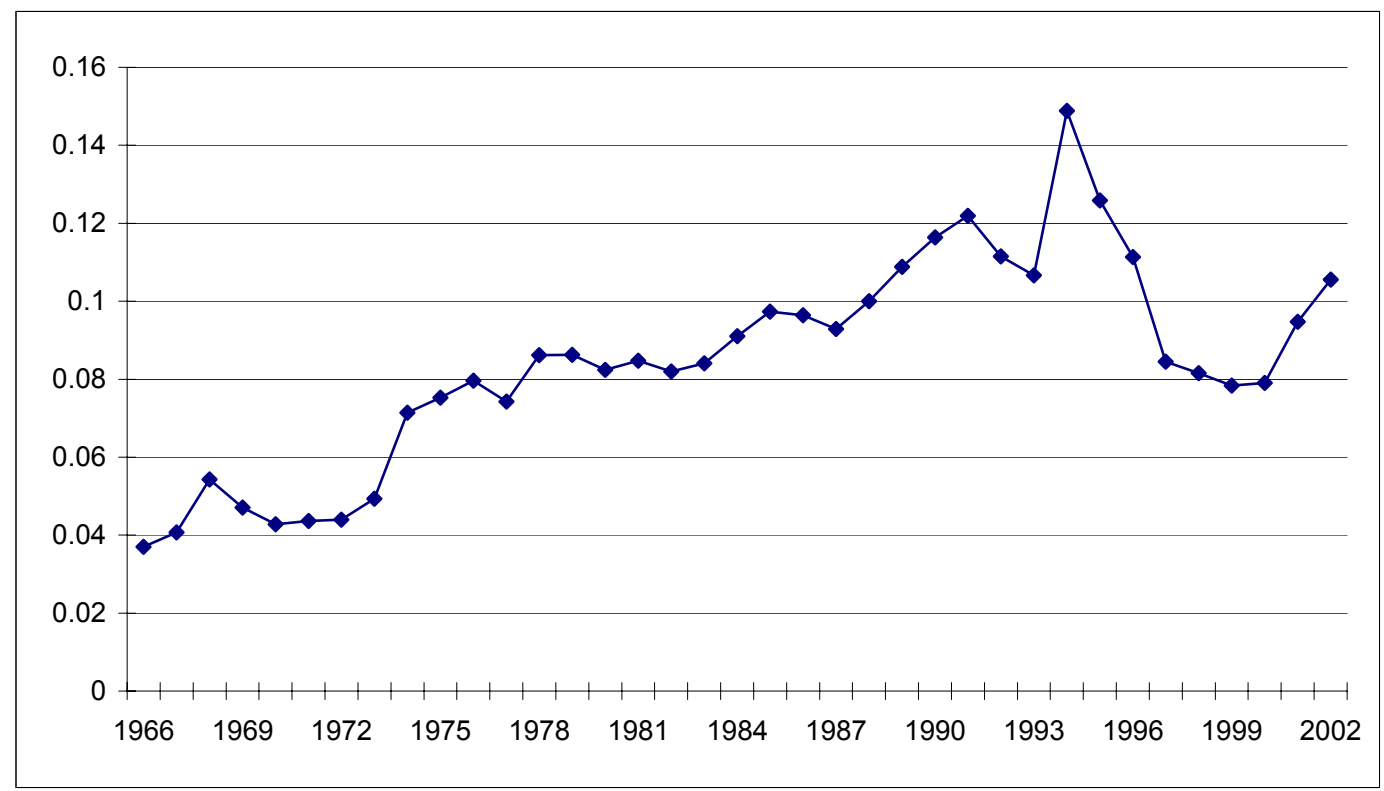

1/ Average across countries, for each period, of individual aid-to-GDP series.

series can be obtained from the data by means of factor analysis. Specifically, following Forni and Reichlin (1998), we measure global aid as the 
cross section average, for each year, of country-specific aid-to-GDP series. This measure of global aid is plotted in Figure 1. As we can see, the series trends upward till the end of the Cold War, in 1991, and then declines steadily, with the exception of three large increases in 1994, 2001, and 2002, associated with the delivery of debt relief from the Paris Club and the HIPC initiative in many countries at the same time. To check the robustness of the analysis to the specific technique with which we construct our global aid variable, we also consider three other approaches to measure the common component of individual aid-to-GDP series. These are a dynamic and a static common factor component and a more conventional first principal component of the individual aid series. As we can see from Figure 2, they give essentially the same results, with sample correlations above 0.9 in all three cases ${ }^{11}$ Simplicity of implementation of the analysis thus suggests to use the simple average as we do, following Forni and Reichlin (1998). How

Figure 2 - Alternative Measures of Global Aid (1966-2002)

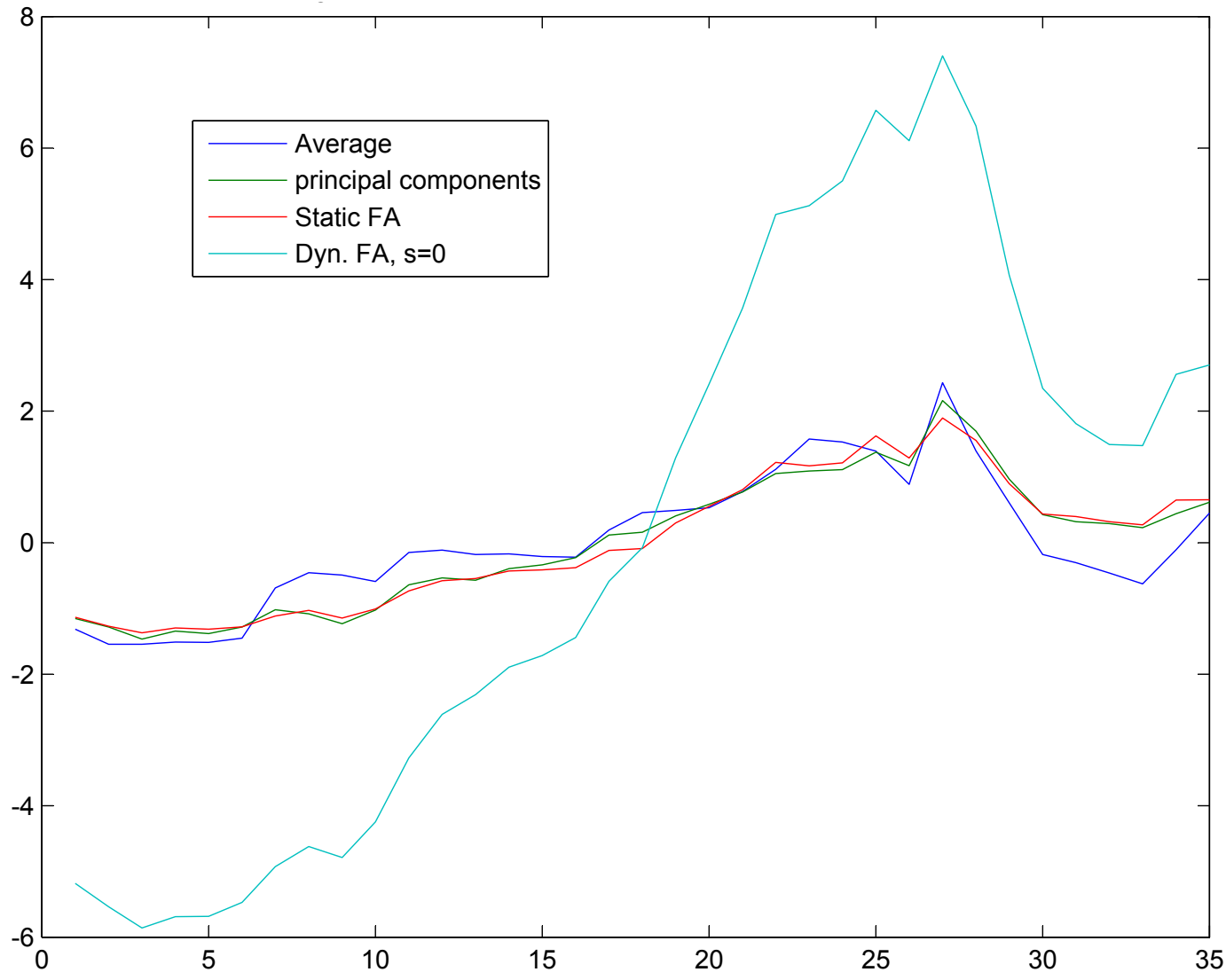

well does global aid correlate with country aid series? In our sample, global

\footnotetext{
${ }^{11}$ Note that the common component measured by the dynamic common factor has a different scale, but a sample correlation of 0.92 with the average aid-to-GDP series. The standard principal component and the static common factor have a correlation of 0.94 and 0.92 with the average aid-to-GDP series, respectively.
} 
aid correlates very well with individual aid-to-GDP series. Table 2 reports the coefficients of country specific OLS regressions of individual aid-to-GDP series on our preferred measure of global aid, which can be interpreted as the loadings onto the common factor. As we can see, the average coefficient is about 0.5 , while the median is almost $0.7 \sqrt{12}$ In addition, as we mentioned in the introduction, the first principal component of these series explains 45 percent of the variability in the aid-to-GDP series in our sample.

Once we constructed a global aid variable, to identify a global aid shock, we need only to assume that global aid does not respond contemporaneously (i.e., within a year) to shocks to the other variables in each country VAR model (per capita GDP growth, exports, and imports) ${ }^{13}$ Given this assumption, an exogenous shock to global aid and associated impulse responses of the other variables can be derived easily from the Cholesky decomposition of the variance covariance matrix of the estimated reduced form residuals of each country VARs (1), with global aid ordered first in the system. 14

But is the critical assumption that global aid does not respond within a year to shocks to the other variables in each VAR justified? For this assumption to be valid, we need to rule out the possibility that reduced form residuals of the growth, export, and import equations in the country VARs might capture shocks that affect the global aid variable within a year. The definition of global aid itself rules out the possibility that country-specific shocks to GDP growth, exports, and imports might affect global aid. This follows directly from the fact that individual aid-receiving countries are too small to affect the average of aid-to-GDP ratios across all aid-receiving countries, which is a key advantage of the identification strategy we propose relative to previous studies. ${ }^{15}$

However, the definition of global variable itself cannot rule out the possibility that the reduced form residuals of the growth, export, and import equations might capture other global shocks, which in turn could in principle affect global aid. Two specific concerns regard the global business cycle and the strong waves of trade liberalization in aid receiving countries of the past two-three decades. Both these two common factors might in princi-

\footnotetext{
${ }^{12}$ The unadjusted standard deviation is about 0.5. Adjusting the sample standard deviation to obtain a consistent mean group estimate of the average loading yields a standard error of 0.08 (See footnote 20 below for details).

${ }^{13}$ As we anticipated discussing estimation issues, we do not need to impose that country aid series do not Granger cause global aid to identify a global aid shock in our model. On the other hand, not imposing such restrictions simplifies significantly estimation of the country VARs, which can rely on OLS rather than full information maximum likelihood.

${ }^{14}$ Note here that, for the purpose of identifying the effects of the global aid shock, the order of the other three endogenous variables in the system does not matter.

${ }^{15}$ As it is well known, aid-dependent economies export primarily to more advanced economies and are not primarily tied to each other and other poor economies. It is therefore unlikely that our key identification assumption is violated due to second-round effects via trade linkages among aid-receiving countries.
} 
Table 2 - Country Loadings on Global Aid ( i.e., Average Aid-to-GDP, 1966-2002) 1/

\begin{tabular}{|c|c|c|c|c|}
\hline Country & OLS Coefficient & Std. error & t-statistic & P-value \\
\hline Burundi & 0.96 & 0.08 & 11.98 & 0.00 \\
\hline Benin & 0.98 & 0.06 & 15.43 & 0.00 \\
\hline Burkina Faso & 0.93 & 0.08 & 11.59 & 0.00 \\
\hline Bangladesh & -0.12 & 0.22 & -0.53 & 0.60 \\
\hline Bolivia & 0.70 & 0.13 & 5.27 & 0.00 \\
\hline Central African Republic & 0.31 & 0.17 & 1.84 & 0.07 \\
\hline Cote D'Ivoire & 0.72 & 0.12 & 5.77 & 0.00 \\
\hline Cameroon & 0.33 & 0.16 & 2.08 & 0.04 \\
\hline Congo & 0.51 & 0.15 & 3.32 & 0.00 \\
\hline Egypt & 0.15 & 0.17 & 0.91 & 0.37 \\
\hline Ethiopia & 0.82 & 0.09 & 9.19 & 0.00 \\
\hline Ghana & 0.73 & 0.12 & 6.01 & 0.00 \\
\hline Honduras & 0.81 & 0.12 & 6.94 & 0.00 \\
\hline Haiti & 0.82 & 0.11 & 7.25 & 0.00 \\
\hline Israel & 0.03 & 0.17 & 0.19 & 0.85 \\
\hline Jordan & -0.29 & 0.16 & -1.82 & 0.08 \\
\hline Kenya & 0.69 & 0.13 & 5.33 & 0.00 \\
\hline Sri Lanka & 0.62 & 0.14 & 4.52 & 0.00 \\
\hline Lesotho & 0.33 & 0.16 & 2.02 & 0.05 \\
\hline Morocco & 0.00 & 0.17 & -0.01 & 0.99 \\
\hline Madagascar & 0.69 & 0.13 & 5.32 & 0.00 \\
\hline Mali & 0.82 & 0.11 & 7.18 & 0.00 \\
\hline Myanmar & 0.47 & 0.16 & 3.00 & 0.00 \\
\hline Mauritania & 0.65 & 0.14 & 4.68 & 0.00 \\
\hline Niger & 0.72 & 0.12 & 5.79 & 0.00 \\
\hline Nicaragua & 0.71 & 0.13 & 5.44 & 0.00 \\
\hline Nepal & 0.90 & 0.10 & 9.40 & 0.00 \\
\hline Pakistan & -0.59 & 0.14 & -4.19 & 0.00 \\
\hline Papua New G. & -0.86 & 0.11 & -7.71 & 0.00 \\
\hline Rwanda & 0.77 & 0.12 & 6.38 & 0.00 \\
\hline Senegal & 0.82 & 0.11 & 7.26 & 0.00 \\
\hline Sierra Leone & 0.61 & 0.14 & 4.22 & 0.00 \\
\hline Chad & 0.77 & 0.12 & 6.32 & 0.00 \\
\hline Togo & 0.60 & 0.14 & 4.31 & 0.00 \\
\hline Tunisia & -0.83 & 0.11 & -7.92 & 0.00 \\
\hline Zaire & 0.23 & 0.18 & 1.32 & 0.19 \\
\hline Zimbabwe & 0.83 & 0.11 & 7.35 & 0.00 \\
\hline Median & 0.69 & & & \\
\hline Mean & 0.47 & & & \\
\hline Standard deviation & 0.48 & & & \\
\hline Adjusted Standard Deviation 2/ & 0.08 & & & \\
\hline
\end{tabular}

1 / Average across countries, for each period, of individual aid-to-GDP series. 2/ See footnote 20 on the adjustment. 
ple induce a positive correlation between global aid and growth, exports, and imports in aid receiving countries, to the extent to which donor policies depend on the state of the global cycles or may reward trade liberalization efforts with additional aid.

To address these concerns, and thus bolster the underpinnings of the our key identifying assumption that the residuals of the reduced form of the growth, export, and import equations do not reflect shocks also affecting global aid within a year, we augment the PVAR system (1) with a small set of control variables $\left(X_{t}^{i}\right)$. These variables aim at "cleaning" the reduced form residuals of the country VARs from the effects of common shocks that might impact contemporaneously global aid and the other variable in the system. This set of variables includes (i) a real commodity export price index based on international commodity prices and (ii) a trading partners' import volume index - both based on IMF World Economic Outlook data and made country-specific using commodity export shares and trade weights that permit capturing the impact of the global cycle on each aid-receiving country in our sample - and (iii) the country-specific index of trade liberalization of Wacziarg and Welch (2008) that captures increases in exports and imports due to trade reforms ${ }^{16}$

\section{Data}

We start by including 55 countries with median aid-to-GDP ratio greater than 2 percent and population above 1 million out of 107 potential aidreceiving countries. These criteria avoid inclusion of countries for which aid is not an important source of foreign financing (e.g., emerging market countries) and artificial sample inflation with small countries.

From these 55 countries, we select 37 countries whose data (both endogenous and exogenous variables) are available for more than 20 years, over the period from 1960 to 2002. Thus, both the cross section and the time dimension of the panel are reasonably sized to address consistency issues of the estimates we want to compute 17

\footnotetext{
${ }^{16}$ Note that good controls for the heterogeneous impact of the global cycle across countries would be needed also in most instrumental variable approaches used in the literature. For example, the time series version of Rajan and Subramanian's (2011) instrumental variable uses individual donors' budgetary positions as a source of exogenous time-series variation. This approach might result in an invalid instrument if the donors' budgetary positions were correlated, as it is likely, with the global cycle. Including time dummies in the panel estimation could not fully address this concern as the impact of the global cycle could be country-specific and, thus, require the estimation of separate coefficients. From this point of view, the PVAR approach of this paper has the advantage of allowing measures of global shocks to affect each variable with a country-specific coefficient (at the cost, of course, of having to select specific indicators of global shocks).

${ }^{17}$ See Judson and Owen (1999) for Monte Carlo simulation evidence on standard dynamic panel data models, and Rebucci (2010a) for Monte Carlo evidence on a PVAR like model (1). Rebucci (2010b) for an application.
} 
We then exclude seven countries because they turn out to display explosive dynamic responses to our global aid shock (namely, Ethiopia, Ghana, Lesotho, Myanmar, Senegal, Chad, and Zimbabwe). As we noted already, in conducting the empirical analysis at the country level for a large number of countries there is always a trade-off between the degree of non-parametric heterogeneity that can be allowed for, which would permit maximizing the number of usable countries included in the sample, and the need to avoid ad hoc assumptions on the model specification of individual countries, which may result in different estimates due to a different model specification. Here, we impose a common model specification across countries, because it eliminates the possibility to have different estimation results due to a different model specifications. The cost, however, is to drop a few countries from the sample that display explosive behavior. This leaves us with 30 countries in the sample.

Note, however, that the average across countries of aid-to-GDP series includes 42 countries for which we have the necessary aid data. Although five countries of these 42 do not have a complete set of series with more than 20 years, there is no reason to exclude them from the computation of the common component of aid-to-GDP, which is our measure of global aid.

\section{Results}

The first main result of the analysis is that, consistent with the weak form of the DD hypothesis that we consider, the long-run comovement between growth and export responses caused by our global aid shock is positive, economically sizable, and statistically significant. This is illustrated by Figure 3 that is a scatter plot of the cumulative response of per capita GDP growth to a global aid shock against the cumulative response of the export-to-GDP ratio to the same shock.

The size of the shock is one-standard deviation, roughly equivalent to one percent of GDP on average among aid-receiving countries on impact, and reaching 2 percent of GDP cumulatively in the long run. As we can see from Figure 3, the p-value of the regression line is very small, and the magnitude of the country effects is sizable, if the global aid shock is scaled realistically (say, for instance, by a factor of 2.5 , as it is done in footnote 22 below). This association is robust to the exclusion of Congo and Nicaragua that may be regarded as outliers. Consistent with the DD hypothesis, the association depicted in Figure 3 suggests that, in response to a global aid shock, per capita output growth falls when export performance deteriorates. What may be explaining this association in our sample of countries? The second main result of the paper suggests that exchange rate overvalaution may drive the DD-like dynamic responses of export and growth to global aid shocks documented in Figure 3. This is borne out by Table 3, which reports univariate OLS regressions of the cumulative responses of growth and ex- 
ports (Panels A and B, respectively) on variables typically used in the literature on aid and growth in 18 This subset of variables was selected from all the co-variates considered by Rajan and Subramanian (2008), by choosing only variables with sample correlation with the cumulative growth response higher than 0.1. The selected set of variables includes three measures of exchange rate overvaluation. 19 As we can see from Table 3, both cumulative growth and export responses are associated with overvaluation measures. Other covariates typically considered in the literature are less closely associated with growth and export responses to the global aid shock. While some other variable selected does correlate with the right sign with the growth and export responses, statistical significance is above standard thresholds only for measures of overvaluation, for both growth and export responses. For instance, financial development (as measured by M2 over GDP) is significant only for the growth response, while the share of multilateral aid is significant only in the case of the export response. ${ }^{20}$

\section{Figure 3 - Per Capita GDP Growth and Export to GDP: Cumulative Impulse Re- sponses to Global Aid Shock}

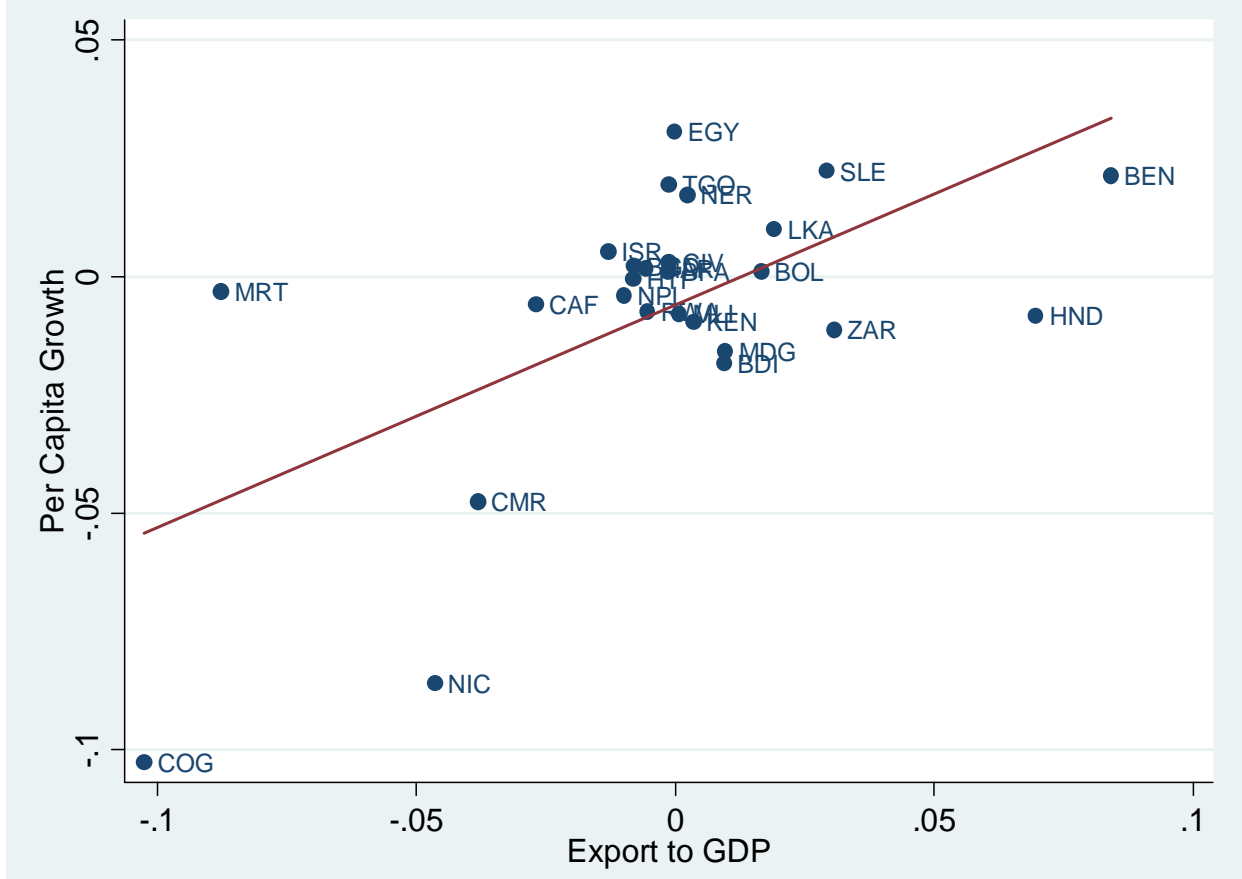

\footnotetext{
${ }^{18}$ Note that the number of countries included in the regressions in Table 3 is 25 rather than 30 because of data availability.

${ }^{19}$ See Table 3 on their sources and definition.

${ }^{20}$ Note that measures of overvaluation and the share of multilateral aid are highly negatively correlated (correlation not reported). This suggests that limiting or preventing overvaluation may be one way through which multilateral involvement matters.
} 


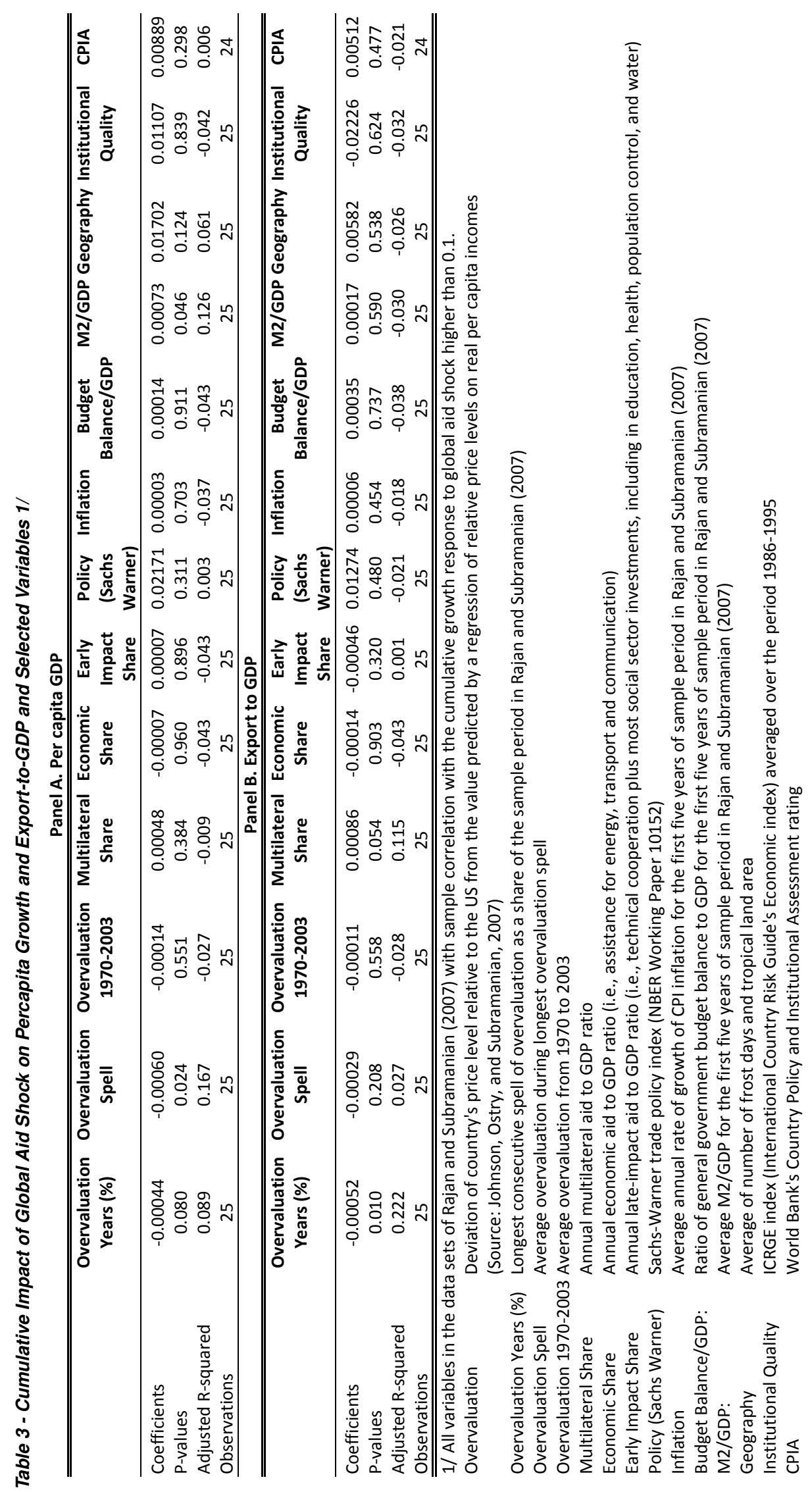


Interestingly, however, the evidence we report indicates that DD is not the end of the story. Figure 3 , in fact, also shows that in about half of the countries in the sample the global aid shock has a positive cumulative effects on both per capita output growth and export.

Figure 4 - Per Capita GDP Growth and Export to GDP: Cumulative Impulse Responses to Global Aid Shock

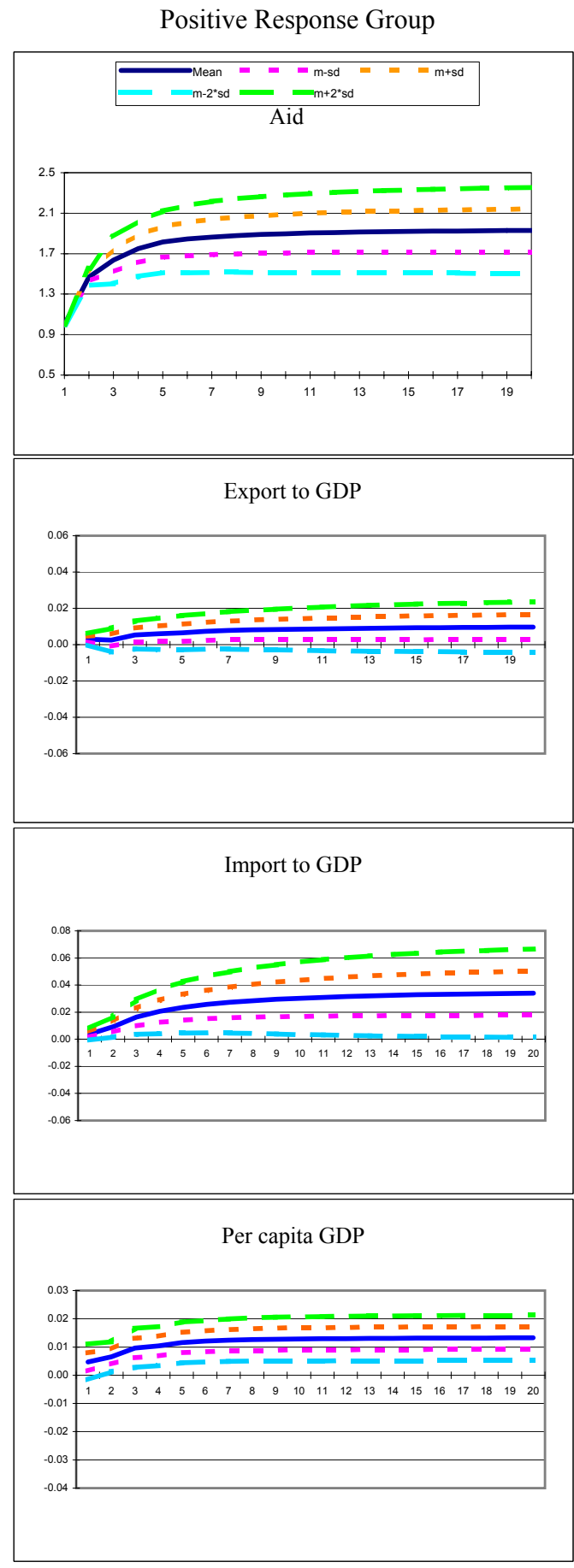

Negative Response Group

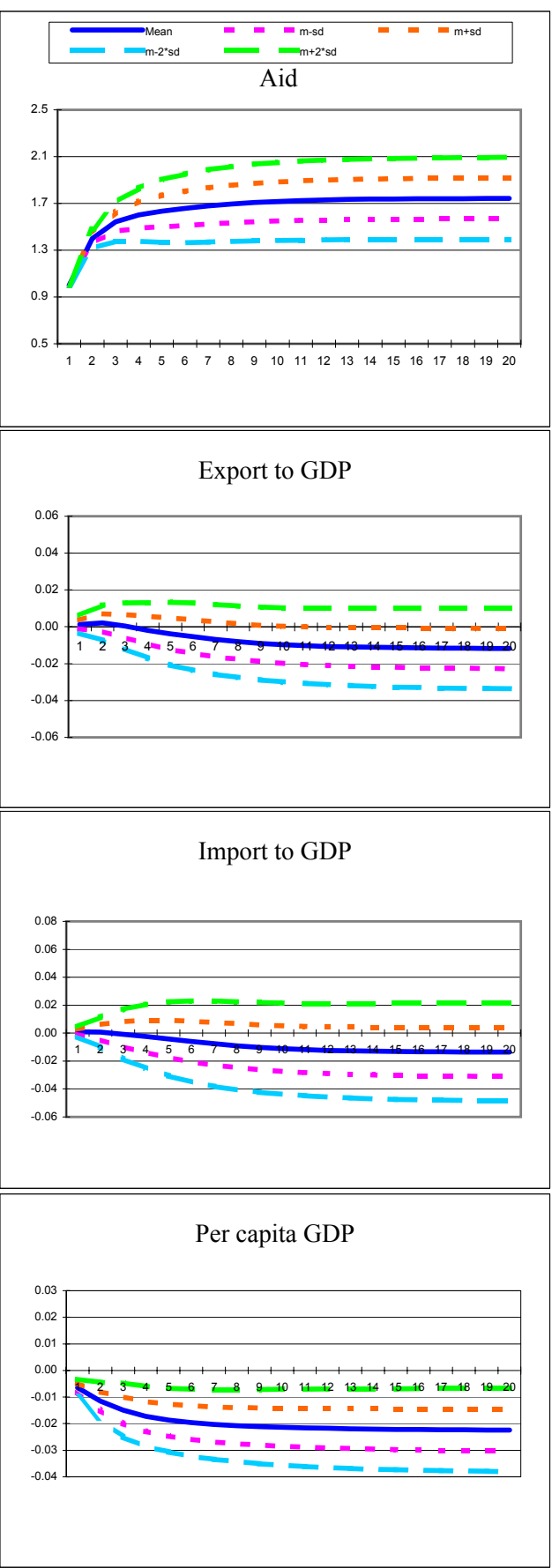


And this is not consistent with the DD hypothesis we consider. To investigate further the association between cumulative growth, export, and import in response to the global aid shock, we split the sample in two groups of countries depending on the sign of the cumulative effect of the global aid shock on growth.

Figure 4 reports these additional results. The panels on the left hand side of the Figure report results for the positive response group, while the panels on the right hand side report results for the negative response group. The Figure plots the mean-group cumulative response to the global aid shock (i.e., the average cumulative response within the group), together with oneand two-standard deviation error bands ${ }^{21}$ As we can see, positive growth responses are associated with positive export and import responses, and vice versa. Note then that, while within each of the two groups the sign of the cumulative effect of the global aid shock on growth is the same by construction, there is no mechanical link with the sign of the cumulative export and import response within group. Thus, the association between the sign of the cumulative response of growth, export and import within each group is a finding of the empirical analysis and not a mechanical consequence of the group selection criterion. Note finally that, the average size of these re-

Table 4 - Country Groups

\begin{tabular}{|c|c|c|c|}
\hline \multicolumn{2}{|c|}{ By GDP response } & \multicolumn{2}{|c|}{ By Export response } \\
\hline Positive & Negative & Positive & Negative \\
\hline Bangladesh & Burundi & Benin & Bangladesh \\
\hline Benin & Cameroon & Bolivia & Burkina Faso \\
\hline Bolivia & Central African Republic & Burundi & Cameroon \\
\hline Burkina Faso & Congo & Honduras & Central African Republic \\
\hline Cote D'Ivoire & Haiti & Jordan & Congo \\
\hline Egypt & Honduras & Kenya & Cote D'Ivoire \\
\hline Israel & Kenya & Madagascar & Egypt \\
\hline Jordan & Madagascar & Mali & Haiti \\
\hline Morocco & Mali & Niger & Israel \\
\hline Niger & Mauritania & Sierra Leone & Mauritania \\
\hline Pakistan & Nepal & Sri Lanka & Morocco \\
\hline Sierra Leone & Nicaragua & Tunisia & Nepal \\
\hline Sri Lanka & Papua New G. & Zaire & Nicaragua \\
\hline \multirow[t]{4}{*}{ Togo } & Rwanda & & Pakistan \\
\hline & Tunisia & & Papua New G. \\
\hline & Zaire & & Rwanda \\
\hline & & & Togo \\
\hline $\mathrm{N}=14$ & $\mathrm{~N}=16$ & $\mathrm{~N}=13$ & $\mathrm{~N}=17$ \\
\hline
\end{tabular}

sponses across group is comparable. It is thus evident that the average im-

${ }^{21}$ We calculate the variance of the mean group cumulative response by taking the variance (across countries for each time period) of individual country responses and dividing it by (1-N). As Pesaran et al. (1995) demonstrate, this adjustment yields a consistent estimate of the true cross-section variance of the mean group response. Note that the computation of these standard errors does not depend on the standard error of the country estimates. 
pact in the entire cross section must be negligible. And as we can see from the panel on the left of Table 4, which reports the country groups, there are 14 countries with a positive cumulative response of GDP per capita and 16 countries with a negative response. The economic magnitude of the effects in Figure 4, in both groups, is sizable. To recall, the one-standard deviation shock to global aid that we consider is equivalent to a shock of about one percent of GDP on average on impact, resulting in cumulative disbursements of 2 percent of GDP on average in the long run. In the case of the positive growth response group, GDP increases cumulatively by about one and a half percent in the long run, while exports and imports expand by one and four percent of GDP, respectively. In the case of the negative growth response group, GDP per capita falls cumulatively by more than two percent, with exports declining cumulatively by about one and a half percent of GDP, and imports also falling by almost two percent of GDP. ${ }^{22}$

The behavior of imports permits to reinforce the interpretation of the results in Figure 4 in terms of the DD hypothesis we focus on. In the long run, in the positive response group (left column of panels in Figure 4), imports increase more than exports by about the same amount as the cumulative aid response (around 2 percent of GDP). Assuming that aid-receiving economies have no access to private international capital markets, this evidence implies that, in this group of countries, foreign aid primarily finances a trade gap between imports and exports rather than the purchase of domestically produced goods, possibly helping to contain exchange rate appreciation and export contraction. In contrast, in the negative response group (right column of panels in Figure 4), the cumulative response of imports is almost identical to the long-run response of exports, with no trade gap opened up by the aid shock. This suggests that, in the negative response group of countries, aid inflows did not finance imports in excess of what can be purchased with export revenues alone, and were more likely spent on domestically produced goods (including non-tradable goods), possibly leading to a real exchange rate appreciation that might affected both export and growth negatively.

The growth and export responses in the two groups of countries in Figure 4 are different statistically by the criterion that is appropriate for our model (i.e., one-standard error band). The growth responses in the two groups are different even using a two-standard error band criterion, while the export responses differ only using a one-standard error band. The use of two-standard error bands, however, is conventional in the context of estimating more restricted structural econometric models, but a lower standard

\footnotetext{
${ }^{22}$ As the VAR system is a linear model, these impulse responses can be scaled up or down as needed. For instance, a cumulated positive global aid shock of 4 percent of GDP (i.e., a two-standard deviation shock), in the negative response group, reduces cumulated imports and exports by about 3 and 4 percent of GDP, respectively, and GDP per capita by 4 percent.
} 
is applied to VAR models that use only minimal structure (Sims, 1987). This suggests that the one-standard error band is an acceptable criterion for our model to use. The additional results reported in Figure 4 are robust to the

Figure 5 - Cumulative Impulse Response to Global Aid Shock (Grouped by Export Response)

Positive response group

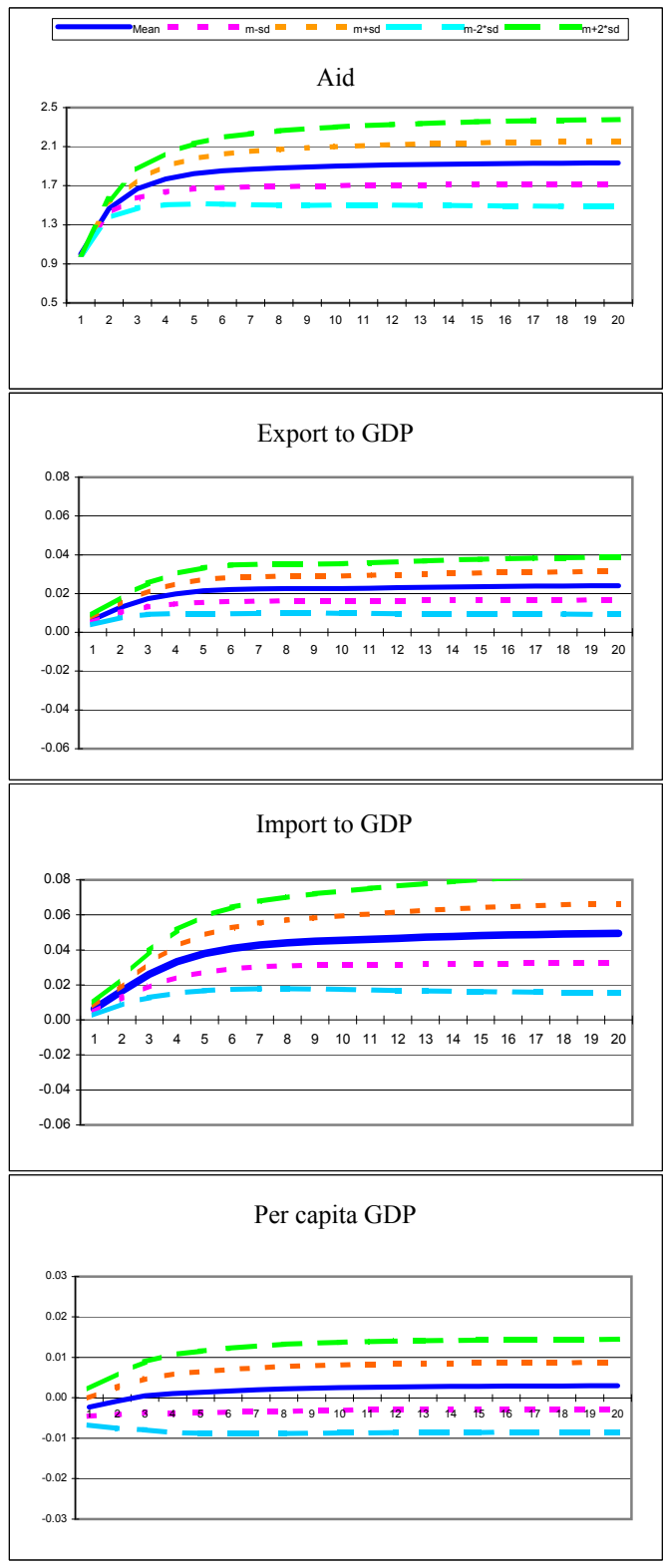

Negative response group

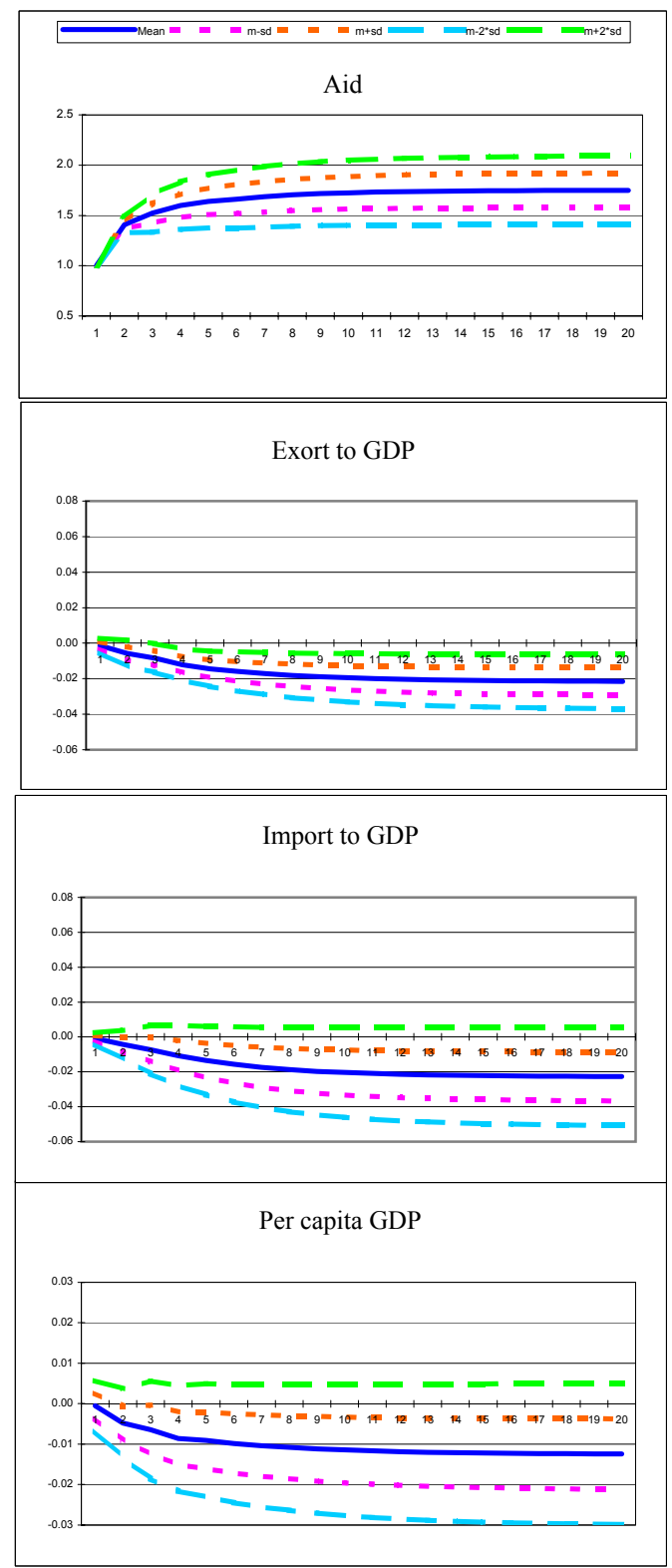

grouping criterion used. To check the robustness of the results along this dimension, Figure 5 reports the same set of dynamic responses grouped according to the sign of the export response to the global aid shock. When we group countries according to the sign of the export responses, we find very similar dynamic responses. In this case, as we can see from the panel on the 
right of Table 4, the cumulative growth and export responses are positive in 13 countries and negative in 17 countries. And, again, the sign differences of the growth and export responses are statistical significant using a one-standard error band criterion.

Finally, it is interesting to ask how important global aid shocks have been, on average, during our sample period, in determining growth and trade flows volatility. The impulse responses in Figures 4 and 5 illustrate the transmission of a one-time shock to global aid on growth, exports, and imports, but not their relative importance. Figure 6 instead reports the variance decompositions of these variables, which help addressing this question, grouped by both growth and export responses. These decompositions show that the share of the variance of per capita growth and export explained by the global aid shock is around 10 percent of total variance (slightly above in the case of exports and slightly below in the case of growth). And this is regardless of the aggregation criterion used (growth or export response), the response group considered (positive or negative), and despite the sizable dynamic effects found in the impulse response analysis. The finding is consistent with the well known fact in the empirical growth literature that the typical growth covariates can explain only a fraction of total growth variability, with an unexplained regression residual that is usually large ${ }^{23}$ In addition, note that, in our case, the large growth residual (the share of growth variance not explained by our global aid shock) is not the consequence of global aid being weakly associated with the individual aid series. Indeed, Table 2 showed that our measure of global aid correlates well with individual country series and explains a significant share of the cross-section variability in aid-to-GDP ratios.

\section{Conclusions}

In this paper we investigated empirically a weak form of the "Dutch disease" hypothesis of the ineffectiveness of aid on growth by using a time series econometric methodology that is novel in this literature: a heterogeneous panel vector-autoregression model identified through factor analysis.

Our main empirical findings are consistent with the weak form of the DD hypothesis that we consider: (i) a global aid shock causes cumulative import, export and per capita GDP growth to comove positively and strongly in the long run, (ii) with export and growth responses correlating closely with measures of exchange rate overvaluation, unlike other typical growth covariates used in the literature.

Nonetheless, the evidence reported in the paper also suggests that not all aid-receiving countries are doomed to catch DD. In about half of the sample, global aid has a negative effect on cumulative exports, imports, and per

\footnotetext{
${ }^{23}$ See Easterly et al. (1993) on the theoretical bounds of the R-square statistic for a typical growth regression.
} 


\section{Figure 6 - Variance Shares Due to Global Aid Shock}

Panel A. Exports to GDP

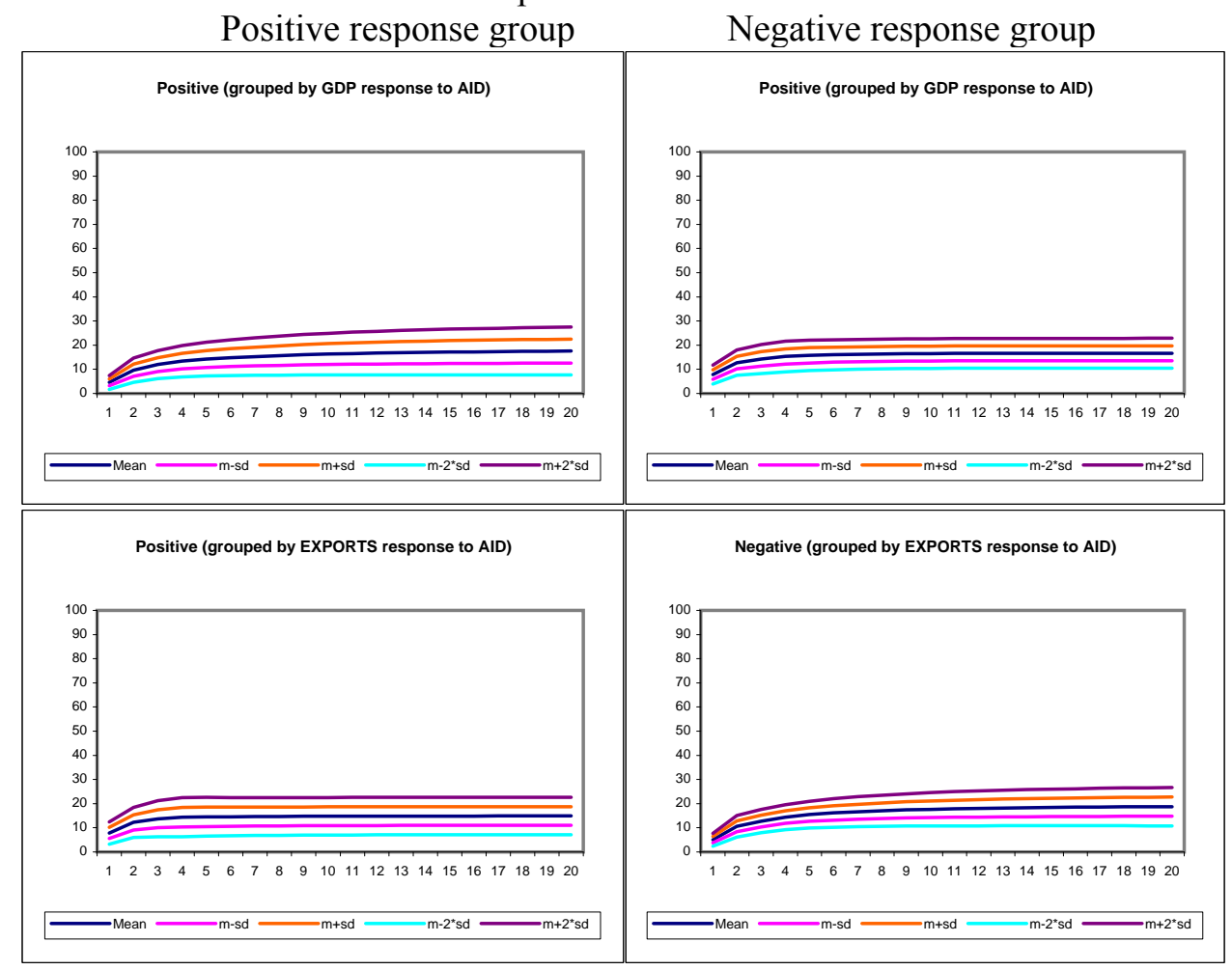

Panel B. Per capita GDP Growth Positive response group

Negative response group

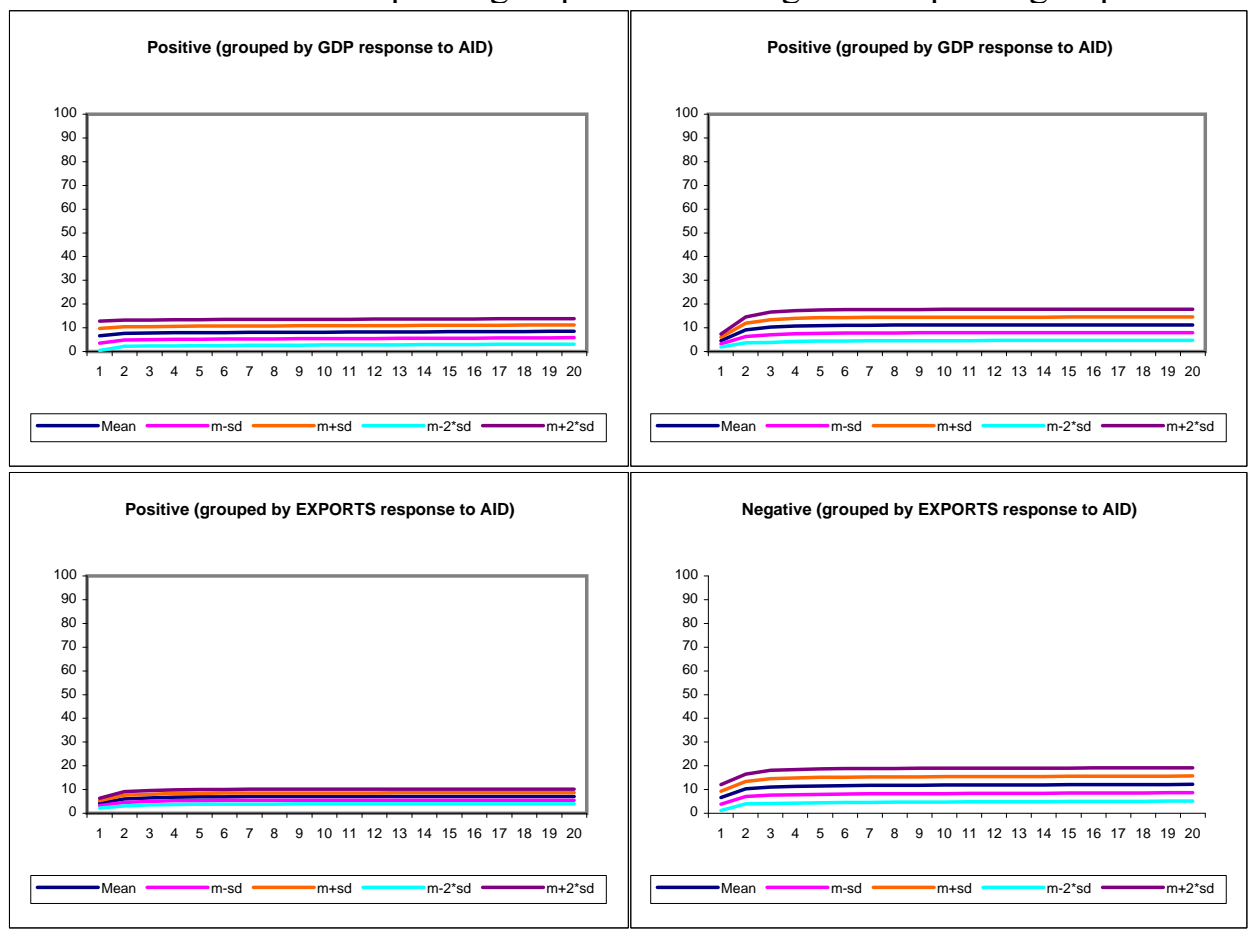


capita GDP growth consistent with the DD hypothesis. In the other half of the sample, however, aid spurs exports, imports, and growth. In both cases, the effects aid shocks are economically sizable and statistically significant. And the quantitative differences in the response of import and export across these two groups of countries suggest that the extent to which aid is spent on imported goods as opposed to domestically produced goods may explain what permits some countries to avoid DD. This further suggest that exchange rate policy should be an important area of focus to try to contain contagion from DD in response to aid inflows.

A question the evidence reported in the paper leaves us with is how, precisely, aid can spur exports and growth. While it is easy to conjecture what could explain such a positive dynamics (e.g., foreign aid might boost productivity and exports through infrastructure projects, such as the construction of ports and roads), our empirical strategy is not designed to discriminate among alternative competing explanations of a positive association between aid, exports, and growth, because it is geared towards identifying and illustrating the DD hypothesis. We therefore leave the task of investigating specific channels through which aid can positively affect exports and growth to future research. 


\section{References}

Attanasio, O.P., Picci L., \& Scorcu, A.E. (2000). Saving, Growth and Investment: a Macroeconomic Analysis Using a Panel of Countries. The Review of Economics and Statistics, 82(2), 182-211. doi:10.1162/003465300558731

Berg, A., Shekhar, A., Hussain, M., Roache, S., Mirzoev, T., \& Mahone, A. (2007). The Macroeconomics of Scaling Up Aid - Lessons from Recent Experiences. (IMF Occasional Paper No. 253). Washington, DC: International Monetary Fund.

Burnside, C., \& Dollar, D. (2000). Aid, Policies, and Growth. American Economic Review, 90(4), 847-868. doi:10.1257/aer.90.4.847

Burnside, C., \& Dollar, D. (2004). Aid, Policies, and Growth: Revisiting the Evidence. (Policy Research Working Paper Series No. 3251). Washington, DC: World Bank.

Canova, F., \& Ciccarelli, M. (2004). Formulation, Estimation and Testing of Bayesian Panel VAR Models. Journal of Econometrics, 120(2), 327-359. doi:10.1016/S0304-4076(03)00216-1

Cerra, V., Tekin, S., \& Turnovsky, S. (2008). Foreign Aid and Real Exchange Rate Adjustment in a Financially Constrained Dependent Economy. Unpublished manuscript.

Clemens, M.A., Radelet, S., \& Bhavnani, R. (2004). Counting Chickens when They Hatch: the Short Term Effect of Aid on Growth. (Working Paper No. 44). Washington, DC: Center for Global Development.

Dalgaard, C-J., Hansen, H., \& Tarp, F. (2004). On the Empirics of Foreign Aid and Growth. The Economic Journal, 114(496), 191-216. doi:10.1111/j.14680297.2004.00219.x

Easterly, W., Kremer, M., Pritchett, L., \& Summers, L.H. (1993). Good Policy or Good Luck? Country Growth Performance and Temporary Shocks. Journal of Monetary Economics, 32(3), pp. 459-483. doi:10.1016/03043932(93)90026-C

Forni, M., \& Reichlin, L. (1998). Let's Get Real: a Factor Analytical Approach to Disaggregated Business Cycle Dynamics. Review of Economic Studies, 65(3), 453-473. doi:10.1111/1467-937X.00053

Hansen, H., \& Tarp, F. (2001). Aid and Growth Regressions. Journal of Development Economics, 64(2), 547-570. doi:10.1016/S0304-3878(00)00150-4

Holtz-Eakin, D., Newey, W., \& Rosen, H. (1988). Estimating Vector Autoregressions with Panel Data. Econometrica, 56(6), 1371-1395. doi:10.2307/1913103 
Johnson, S., Ostry, J.D., \& Subramanian, A. (2007). The Prospects for Sustained Growth in Africa: Benchmarking the Constraints. (IMF Working Paper No. 07/52). Washington, DC: International Monetary Fund.

Jones, C. (1995). Time Series Tests of Endogenous Growth Models. Quarterly Journal of Economics, 110(2), 495-525. doi:10.2307/2118448

Judson, R.A., \& Owen, A.L. (1999). Estimating Dynamic Panel Data Models: a Guide for Macro-Econometricians. Economic Letters, 65(1), 9-15. doi:10.1016/S0165-1765(99)00130-5

Lee, K., Pesaran, M.H., \& Smith, R. (1998). Growth Empirics: A Panel Data Approach - A Comment. Quarterly Journal of Economics, 113(1), 319- 323. doi:10.1162/003355398555504

Pesaran, M.H., \& Smith, R. (1995). Estimating Long-Run Relationships from Dynamic Heterogeneous Panels. Journal of Econometrics, 68(1), 79-113. doi:10.1016/0304-4076(94)01644-F

Pesaran, M.H., \& Smith, R., \& Im, K. (1995). Dynamic Linear Models for Heterogeneous Panels. In L. Mátyás \& P. Sevestre (Eds.), The Econometrics of Panel Data: a Handbook of the Theory with Applications (pp. 145-195). London: Kluwer Academic Publishers.

Prati, A., \& Tressel, T. (2006). Aid Volatility and Dutch Disease: Is There a Role for Macroeconomic Policies? (IMF Working Paper No. 06/145). Washington, DC: International Monetary Fund.

Rajan, R., \& Subramanian, A. (2008). Aid and Growth: What Does the CrossCountry Evidence Really Show?. The Review of Economics and Statistics, 90(4), 643-665. doi:10.1162/rest.90.4.643

Rajan, R., \& Subramanian, A. (2011). Aid, Dutch Disease, and Manufacturing Growth. Journal of Development Economics, 94(1), 106-118. doi:10.1016/j.jdeveco.2009.12.004

Rebucci, A. (2010a). Estimating VARs with Long Stationary Heterogeneous Panels: a Comparison of the Fixed Effect and the Mean Group Estimators. Economic Modelling, 27(5), 1183-1198. doi:10.1016/j.econmod.2010.03.001

Rebucci, A. (2010b). Is Growth Exogenous? Evidence from the 1970s and the 1980s. Applied Economics, 42(5), 535-543. doi:10.1080/00036840701704410

Rodrik, D. (1999). Where Did All the Growth Go? External Shocks, Social Conflict and Growth Collapses. Journal of Economic Growth, 4(4), 385-412. doi:10.1023/A:1009863208706 
Roodman, D. (2007). The Anarchy of Numbers: Aid, Development, and Crosscountry Empirics. (Working Paper No. 32). Washington, DC: Center for Global Development

Sachs, J., \& Warner, A. (1995). Economic Reform and the Process of Global Integration. Brooking Papers on Economic Activity, 1995(1), 1-118. doi: $10.2307 / 2534573$

Smith, R., \& Fuertes, A. (2007). Panel Time Series: A Survey. Unpublished manuscript. Londo: Birkbeck College.

Wacziarg, R., \& Welch, K.H. (2008). Trade Liberalization and Growth: New Evidence. The World Bank Economic Review, 22(2), 187-231. 